\title{
Preliminary Investigation and Research on Soil Pollution of an Industrial Land
}

\author{
Xiangmei Li ${ }^{1,2}$, Honggui Chen ${ }^{1,2 *}$, Hui Tan ${ }^{1,2}$ \\ ${ }^{1}$ Sinosteel Ma'anshan General Institute of Mining Research Co., Ltd., \\ Ma'anshan 243000, Anhui, China \\ ${ }^{2}$ The National Engineering Technology Research Center of Solid Waste Treatment and Disposal for Metal Mines, \\ Ma'anshan 243000, Anhui, China \\ *Correspondence Author
}

\begin{abstract}
The land use of an industrial land was changed to residential land. In order to protect human health, soil pollution survey was carried out before development and utilization. The first stage of pollution identification demonstrates that the site was once used to operate a garage and there is potential pollution sources. In the second stage of soil pollution based investigation, 32 soil sampling sites were set up and 47 kinds of pollutants were detected. The sample analysis results showed that the detected values of each detection factor were lower than the corresponding screening value requirements, and the soil environmental risk of the plot was acceptable.
\end{abstract}

Keywords: Soil pollution, Field sampling, Preliminary investigation.

\section{Introduction}

In recent years, China has witnessed rapid development of urbanization. An important reason for China's rapid urbanization lies in the promotion of land, which has promoted China's rapid urbanization process of different levels and scales in a short period of time. With the acceleration of China's urbanization process, people are keenly in need of improving the living environment[1]. In order to meet people's increasing requirements for housing upgrading, and to solve some remnant industrial land, shelved and uncompleted development due to various reasons, part of the industrial land was converted into residential land[2]. However, many of these industrial lands have been used for industrial purposes. In the process of industrial activities, some toxic and harmful substances may enter the soil and groundwater through atmospheric subsidence and surface water migration[3]. Therefore, it is necessary to investigate and evaluate the possible soil pollution before residential construction of such plots. If there are any problems, they should be repaired before development. In this study, a plot with a garage was built and operated as the object. By means of soil sampling and testing, the pollution during the industrial use of the plot was analyzed and evaluated to judge whether the plot could be used as a suitable land for residential development.

\section{Research Contents and Methods}

\subsection{Overview of Contaminated Sites}

The investigated plot is located in a city in the lower reaches of the Yangtze River, with a total planned construction land area of $114,894.05 \mathrm{~m}^{2}$. The site used to be industrial land, and the former user was a science and technology company, which belongs to the computer, communication and other electronic equipment manufacturing industry. However, due to financial reasons, substantive production and operation activities have not been carried out in this site. Some of the completed buildings are rented by relevant developers to car repair shops and training institutions. Now the buildings in the plot are abandoned. The buildings in the site have been abandoned and closed, with no production activities. According to the identification of UAV (unmanned aerial vehicle) image, there are a small amount of domestic garbage scattered in the open area, and there are two places of water on the surface in the south of the plot, and the rest are natural vegetation. See Figure 1 for the specific site situation.

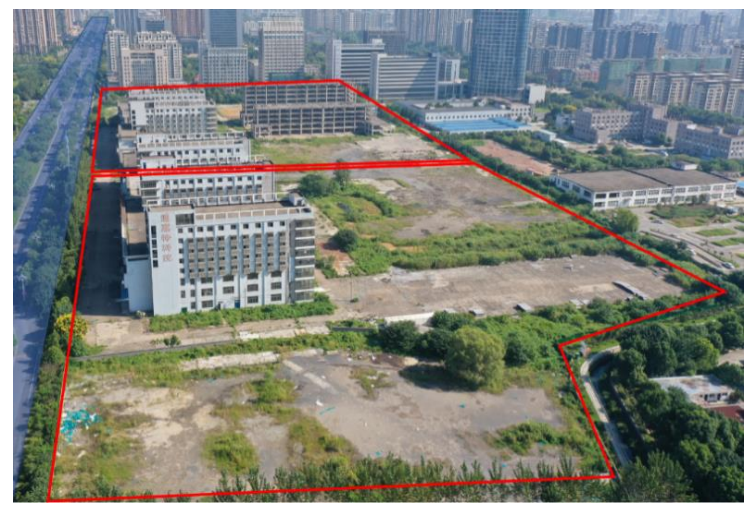

Figure 1: Field map

Based on the historical usage of the plot and the data collected from the investigation, it is preliminarily determined that the possible pollution sources in the investigated plot are mainly the automobile repair shop in the north plot and the waste oil generated from the temporary parking lot in some areas in the south plot, and the characteristic pollution factor is petroleum hydrocarbon.

\subsection{Layout of Zoning and Soil Sampling Sites}

\subsubsection{Plot zoning}

According to the site utilization change data and site production data collected in the first stage of the survey, the sampling method is used to divide the investigated plot into four zones: A, B, C and D ( $\mathrm{A}$ is the original site road, B is the original production office area, $\mathrm{C}$ is the original parking lot, and $\mathrm{D}$ is the unfinished building). 
Sampling depth According to HJ25.2-2019, the sampling depth deducts the thickness of non-soil hardening layer on the surface. In principle, $0 \sim 0.5 \mathrm{~m}$ topsoil soil samples should be collected, and lower soil samples below $0.5 \mathrm{~m}$ should be collected according to the judgment distribution method. It is recommended that the interval between $0.5 \sim 6 \mathrm{~m}$ soil samples should not exceed $2 \mathrm{~m}$. To collect at least one soil sample from different soil layers. When the soil layer with the same property is thick or has obvious pollution traces, the collection points should be added to this layer according to the actual situation. In general, the sampling depth of subsoil should be determined according to the phased conclusion of soil pollution investigation and the on-site situation, and the maximum depth should be up to the unpolluted depth. The FAST PID detection data were taken as the main screening basis, and the samples with high PID readings were selected as the target analysis and test. At the same time, XRF fast data are also used as reference. CK site was originally located in an orthopedic hospital on the east side of the investigation plot, but considering that the application of farm manure in the planting process may increase the content of heavy metals in the soil, CK site was moved to a driving school on the southeast side of the investigation plot.

\subsubsection{Layout of sampling points}

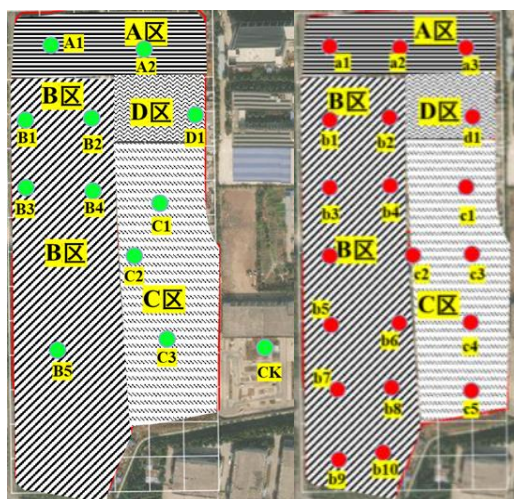

Figure 2: Distribution of sampling points of soil fast-screen sample and columnar sample
Soil quick screening samples were divided into a sampling unit of $80 \times 80 \mathrm{~m}$, and the surface soil of $0 \sim 0.5 \mathrm{~m}$ was tested once at 20 fast screening sites. There are 12 columnar samples in total. In principle, one sample is taken from 0 to $0.5 \mathrm{~m}$, one sample is taken every $2 \mathrm{~m}$ from $0.5 \mathrm{~m}$ to the initial diving layer, and one sample is taken from each layer of different soil structure layer. The actual sampling depth can be adjusted according to the actual situation and sensory judgment results. Distribution of sampling points of soil fast-screen sample and columnar sample is shown in Figure 2.

\subsubsection{Sample collection}

According to the sampling scheme sampling by hole drilling is carried out on the distribution area of the investigation site. After reaching the target depth, the columnar soil is taken out from the sampling tube. After the sampling tube is cut open and the depth range of the soil is determined, the undisturbed soil in the middle part is put into the corresponding sampling bag or sampling bottle. The basic requirement of sample collection is to minimize soil disturbance and ensure that the soil samples are not contaminated by secondary contamination in the sampling process.

\subsection{Test Item based Analysis Method and Evaluation Criteria}

According to the identification of the pollution status in the plot and according to the Soil Pollution Risk Control Standard for Construction Land GB36600-2018 (Trial)[4], the detection items of the column samples are 7 heavy metals and inorganic substances, 38 volatile and semi-volatile organic compounds, and soil $\mathrm{pH}$ and petroleum hydrocarbon, a total of 47 indicators. The test items of fast screening samples are $\mathrm{As}, \mathrm{Cr}, \mathrm{Cd}, \mathrm{Cu}, \mathrm{Pb}, \mathrm{Hg}, \mathrm{Ni}$ and $\mathrm{PID}$, and the first type of construction land is used for screening values. The detection methods of each detection index are shown in Table 1.

Table 1: Items and methods of soil measurement in the survey plot

\begin{tabular}{|c|c|c|c|}
\hline No. & Testing items & Analysis method & $\begin{array}{l}\text { Consistency of the analysis method with } \\
\text { GB 36600-2018 }\end{array}$ \\
\hline 1 & Cadmium & GB/T 17141-1997Soil quality -- Determination of lead and & \multirow{2}{*}{ Consistent } \\
\hline 2 & Plumbum & cadmium -- Graphite furnace atomic absorption spectrophotometry & \\
\hline 3 & Mercury & $\begin{array}{c}\text { Soil quality -- Determination of total mercury, total arsenic, total } \\
\text { lead -- Atomic fluorescence method -- Part 1: Determination of } \\
\text { total mercury in soil -- GB/T 22105. 1-2008 }\end{array}$ & Consistent \\
\hline 4 & Arsenic & $\begin{array}{c}\text { Soil quality -- Determination of total mercury, total arsenic, total } \\
\text { lead -- Atomic fluorescence method -- Part 2: Determination of } \\
\text { total arsenic in soil -- GB/T 22105. 2-2008 }\end{array}$ & Consistent \\
\hline 5 & Cr VI(chromium VI) & $\begin{array}{c}\text { Soil and sediment -- Determination of hexavalent chromium -- } \\
\text { Alkali solution extraction -- Flame atomic absorption } \\
\text { spectrophotometry HJ 1082-2019 }\end{array}$ & Consistent \\
\hline 6 & Nickel & \multirow{2}{*}{$\begin{array}{l}\text { Soil and sediment -- Determination of copper, zinc, lead, nickel and } \\
\text { chromium -- Flame atomic absorption spectrophotometric method } \\
\text { HJ 491-2019 }\end{array}$} & \multirow{2}{*}{$\begin{array}{l}\text { It is consistent with GB36600-2018, but the } \\
\text { standard numbers are different* }\end{array}$} \\
\hline 7 & Copper & & \\
\hline 8 & $\mathrm{pH}$ & $\begin{array}{l}\text { Determination of soil } \mathrm{pH} \text { value by potentiometric method } \mathrm{HJ} \\
962-2018\end{array}$ & $\begin{array}{c}\text { GB 36600-2018 does not provide this } \\
\text { indicator }\end{array}$ \\
\hline 9 & Chloromethane & \multirow{9}{*}{$\begin{array}{l}\text { Soil and sediment - Determination of volatile organic compounds - } \\
\text { Purge and capture - Gas chromatography-mass spectrometry HJ } \\
605-2011\end{array}$} & \multirow{9}{*}{ Consistent } \\
\hline 10 & Chloroethylene & & \\
\hline 11 & 1,1-dichloroethylene & & \\
\hline 12 & Dichloromethane & & \\
\hline 13 & Anti-1,2-dichloroethylene & & \\
\hline 14 & 1,1-Dichloroethane & & \\
\hline 15 & Cis-1,2-Dichloroethylene & & \\
\hline 16 & Chloroform & & \\
\hline 17 & 1,1,1-Trichloroethane & & \\
\hline
\end{tabular}




\begin{tabular}{|c|c|c|c|}
\hline 18 & carbon tetrachloride & & \\
\hline 19 & Benzene & & \\
\hline 20 & 1,2-Dichloroethane & & \\
\hline 21 & Trichloro ethylene & & \\
\hline 22 & 1,2-Dichloropropane & & \\
\hline 23 & Methylbenzene & & \\
\hline 24 & 1,2- Trichloroethane & & \\
\hline 25 & Tetrachloroethylene & & \\
\hline 26 & Chlorobenzene & & \\
\hline 27 & $1,1,1,2$-Tetrachloroethane & \multirow{9}{*}{$\begin{array}{l}\text { Soil and sediment -- Determination of volatile organic compounds } \\
\text {-- Purge and capture/Gas chromatography-mass spectrometry HJ } \\
605-2011\end{array}$} & \multirow{9}{*}{ Consistent } \\
\hline 28 & Ethylbenzene & & \\
\hline 29 & Parachlormetaxylenol & & \\
\hline 30 & OX(ortho-xylene) & & \\
\hline 31 & Styrene & & \\
\hline 32 & 1,1,2,2-Tetrachloroethane & & \\
\hline 33 & 1,2,3-Trichloropropane & & \\
\hline 34 & 1,4-Dichlorobenzene & & \\
\hline 35 & 1,2 - dichlorobenzene & & \\
\hline 36 & 2 - Chlorophenol & \multirow{11}{*}{$\begin{array}{l}\text { Determination of semi-volatile organic compounds in soil and } \\
\text { sediment by Gas chromatography-mass spectrometry HJ 834-2017 }\end{array}$} & \multirow{11}{*}{ Consistent } \\
\hline 37 & nitrobenzene & & \\
\hline 38 & Aniline & & \\
\hline 39 & Dibenzo $(\mathrm{A}, \mathrm{H})$ anthracene & & \\
\hline 40 & Benzo [a] pyrene & & \\
\hline 41 & Benzo [b] fluoranthene & & \\
\hline 42 & Benzo $[\mathrm{K}]$ fluoranthene & & \\
\hline 43 & Chrysene & & \\
\hline 44 & Dibenzoanthracene & & \\
\hline 45 & Indene $[1,2,3-\mathrm{Cd}]$ pyrene & & \\
\hline 46 & Naphthalene & & \\
\hline
\end{tabular}

Note: *According to the Announcement of the Ministry of Ecology and Environment on the issuance of six national environmental protection standards such as Technical Guidelines for Sampling Volatile Organic Compounds from Soil and Groundwater of Land Parcel (Announcement No. 15, 2019), HJ 491-2019 will replace GB/T 17138-1997, GB/T 17139-1997 and HJ 491-2009 on September 1, 2019.

\section{Results and Discussions}

\subsection{Test Results}

Table 2 shows the maximum values of soil test indexes at different depths at all borehole sampling points, and all test indexes are less than the first type of land use screening values and Control values in Table 1 soil pollution Risk Screening values and Control Values for Construction Land in Soil Environmental Quality Risk Control Standards for Soil Pollution in Construction Land (Trial) (GB 36600-2018).

Table 2: Results of soil test

\begin{tabular}{|c|c|c|c|c|c|c|c|c|c|c|c|c|c|c|}
\hline $\begin{array}{c}\text { Testing } \\
\text { indicator }\end{array}$ & Sample name & $\mathrm{A} 1$ & A2 & B1 & B2 & B3 & B4 & B5 & $\mathrm{C} 1$ & $\mathrm{C} 2$ & $\mathrm{C} 3$ & D1 & CK & Unit \\
\hline \multirow{8}{*}{$\begin{array}{c}\text { Heavy metals } \\
\text { and inorganic } \\
\text { substance }\end{array}$} & $\mathrm{pH}$ & 8.09 & 8.34 & 8.5 & 8.09 & 8.7 & 8.12 & 8.73 & 8.93 & 8.8 & 8.89 & 8.68 & 8.44 & \\
\hline & As & 16.1 & 16.5 & 18.7 & 17.6 & 16.1 & 18.2 & 18.9 & 18.9 & 17.6 & 17.6 & 18.9 & 18.5 & $\mathrm{mg} / \mathrm{kg}$ \\
\hline & $\mathrm{Cd}$ & 0.03 & 0.07 & 0.05 & 0.06 & 0.25 & 0.06 & 0.16 & 0.11 & 0.21 & 0.44 & 0.26 & 0.22 & $\mathrm{mg} / \mathrm{kg}$ \\
\hline & $\mathrm{Cr}$ & 0 & 0 & 0 & 0 & 0 & 0 & 0 & 0 & 0 & 0 & 0 & 0 & $\mathrm{mg} / \mathrm{kg}$ \\
\hline & $\mathrm{Cu}$ & 29 & 34 & 29 & 29 & 35 & 33 & 29 & 26 & 56 & 30 & 33 & 32 & $\mathrm{mg} / \mathrm{kg}$ \\
\hline & $\mathrm{Pb}$ & 13.3 & 15.2 & 15.4 & 17.5 & 18.7 & 19 & 19.1 & 24.8 & 19.8 & 21.8 & 9.4 & 13.8 & $\mathrm{mg} / \mathrm{kg}$ \\
\hline & $\mathrm{Hg}$ & 0.032 & 0.17 & 0.161 & 0.114 & 0.36 & 0.1 & 0.178 & 0.091 & 0.155 & 0.052 & 0.214 & 0.187 & $\mathrm{mg} / \mathrm{kg}$ \\
\hline & $\mathrm{Ni}$ & 34 & 39 & 30 & 34 & 39 & 37 & 34 & 34 & 26 & 41 & 20 & 28 & $\mathrm{mg} / \mathrm{kg}$ \\
\hline \multirow{27}{*}{$\begin{array}{l}\text { Volatile } \\
\text { organic } \\
\text { compound } \\
\text { (voc) }\end{array}$} & Carbon tetrachloride & 0 & 0 & 0 & 0 & 0 & 0 & 0 & 0 & 0 & 0 & 0 & 0 & $\mu \mathrm{g} / \mathrm{kg}$ \\
\hline & Chloroform & 0 & 0 & 0 & 0 & 0 & 0 & 0 & 0 & 0 & 0 & 0 & 0 & $\mu \mathrm{g} / \mathrm{kg}$ \\
\hline & Chloromethane & 0 & 0 & 0 & 0 & 0 & 0 & 0 & 0 & 0 & 0 & 0 & 0 & $\mu \mathrm{g} / \mathrm{kg}$ \\
\hline & 1,1-Dichloroethane & 0 & 0 & 0 & 0 & 0 & 0 & 0 & 0 & 0 & 0 & 0 & 0 & $\mu \mathrm{g} / \mathrm{kg}$ \\
\hline & 1,2-Dichloroethane & 0 & 0 & 0 & 0 & 0 & 0 & 0 & 0 & 0 & 0 & 0 & 0 & $\mu \mathrm{g} / \mathrm{kg}$ \\
\hline & 1,1-Dichloroethylene & 0 & 0 & 0 & 0 & 0 & 0 & 0 & 0 & 0 & 0 & 0 & 0 & $\mu \mathrm{g} / \mathrm{kg}$ \\
\hline & Cis-1,2-Dichloroethylene & 0 & 0 & 0 & 0 & 0 & 0 & 0 & 0 & 0 & 0 & 0 & 0 & $\mu \mathrm{g} / \mathrm{kg}$ \\
\hline & Trans-1,2-Dichloroethylene & 0 & 0 & 0 & 0 & 0 & 0 & 0 & 0 & 0 & 0 & 0 & 0 & $\mu \mathrm{g} / \mathrm{kg}$ \\
\hline & Dichloromethane & 0 & 0 & 0 & 0 & 0 & 0 & 0 & 0 & 0 & 0 & 0 & 0 & $\mu \mathrm{g} / \mathrm{kg}$ \\
\hline & 1,2-Dichloropropane & 0 & 0 & 0 & 0 & 0 & 0 & 0 & 0 & 0 & 0 & 0 & 0 & $\mu \mathrm{g} / \mathrm{kg}$ \\
\hline & $1,1,1,2$-Tetrachloroethane & 0 & 0 & 0 & 0 & 0 & 0 & 0 & 0 & 0 & 0 & 0 & 0 & $\mu \mathrm{g} / \mathrm{kg}$ \\
\hline & 1,1,2,2-Tetrachloroethane & 0 & 0 & 0 & 0 & 0 & 0 & 0 & 0 & 0 & 0 & 0 & 0 & $\mu \mathrm{g} / \mathrm{kg}$ \\
\hline & Tetrachloroethylene & 0 & 0 & 0 & 0 & 0 & 0 & 0 & 0 & 0 & 0 & 0 & 0 & $\mu \mathrm{g} / \mathrm{kg}$ \\
\hline & 1,1,1-Trichloroethane & 0 & 0 & 0 & 0 & 0 & 0 & 0 & 0 & 0 & 0 & 0 & 0 & $\mu \mathrm{g} / \mathrm{kg}$ \\
\hline & 1,1,2-Trichloroethane & 0 & 0 & 0 & 0 & 0 & 0 & 0 & 0 & 0 & 0 & 0 & 0 & $\mu \mathrm{g} / \mathrm{kg}$ \\
\hline & Trichloro Ethylene & 0 & 0 & 0 & 0 & 0 & 0 & 0 & 0 & 0 & 0 & 0 & 0 & $\mu \mathrm{g} / \mathrm{kg}$ \\
\hline & 1,2,3-Trichloropropane & 0 & 0 & 0 & 0 & 0 & 0 & 0 & 0 & 0 & 0 & 0 & 0 & $\mu \mathrm{g} / \mathrm{kg}$ \\
\hline & Chloroethylene & 0 & 0 & 0 & 0 & 0 & 0 & 0 & 0 & 0 & 0 & 0 & 0 & $\mu \mathrm{g} / \mathrm{kg}$ \\
\hline & Benzene & 0 & 0 & 0 & 0 & 0 & 0 & 0 & 0 & 0 & 0 & 0 & 0 & $\mu \mathrm{g} / \mathrm{kg}$ \\
\hline & Chlorobenzene & 0 & 0 & 0 & 0 & 0 & 0 & 0 & 0 & 0 & 0 & 0 & 0 & $\mu \mathrm{g} / \mathrm{kg}$ \\
\hline & 1,2-Dichlorobenzene & 0 & 0 & 0 & 0 & 0 & 0 & 0 & 0 & 0 & 0 & 0 & 0 & $\mu \mathrm{g} / \mathrm{kg}$ \\
\hline & 1,4-Dichlorobenzene & 0 & 0 & 0 & 0 & 0 & 0 & 0 & 0 & 0 & 0 & 0 & 0 & $\mu \mathrm{g} / \mathrm{kg}$ \\
\hline & Ethylbenzene & 0 & 0 & 0 & 0 & 0 & 0 & 0 & 0 & 0 & 0 & 0 & 0 & $\mu \mathrm{g} / \mathrm{kg}$ \\
\hline & Styrene & 0 & 0 & 0 & 0 & 0 & 0 & 0 & 0 & 0 & 0 & 0 & 0 & $\mu \mathrm{g} / \mathrm{kg}$ \\
\hline & Methylbenzene & 0 & 0 & 0 & 0 & 0 & 0 & 0 & 0 & 0 & 0 & 0 & 0 & $\mu \mathrm{g} / \mathrm{kg}$ \\
\hline & M-xylene + p-xylene & 0 & 0 & 0 & 0 & 0 & 0 & 0 & 0 & 0 & 0 & 0 & 0 & $\mu \mathrm{g} / \mathrm{kg}$ \\
\hline & OX (ortho-xylene) & 0 & 0 & 0 & 0 & 0 & 0 & 0 & 0 & 0 & 0 & 0 & 0 & $\mu \mathrm{g} / \mathrm{kg}$ \\
\hline \multirow{4}{*}{$\begin{array}{c}\text { Semi-volatile } \\
\text { Organic } \\
\text { Compounds }\end{array}$} & Nitrobenzene & 0 & 0 & 0 & 0 & 0 & 0 & 0 & 0 & 0 & 0 & 0 & 0 & $\mathrm{mg} / \mathrm{kg}$ \\
\hline & Aniline & 0 & 0 & 0 & 0 & 0 & 0 & 0 & 0 & 0 & 0 & 0 & 0 & $\mathrm{mg} / \mathrm{kg}$ \\
\hline & 2-Chlorophenol & 0 & 0 & 0 & 0 & 0 & 0 & 0 & 0 & 0 & 0 & 0 & 0 & $\mathrm{mg} / \mathrm{kg}$ \\
\hline & Dibenzoanthracene & 0.2 & 0 & 0 & 0 & 0 & 0 & 0 & 0 & 0 & 0.1 & 0 & 0 & $\mathrm{mg} / \mathrm{kg}$ \\
\hline
\end{tabular}




\begin{tabular}{|c|c|c|c|c|c|c|c|c|c|c|c|c|c|c|}
\hline $\begin{array}{l}\text { Testing } \\
\text { indicator }\end{array}$ & Sample name & A1 & A2 & $\mathrm{B} 1$ & B2 & B3 & B4 & B5 & $\mathrm{C} 1$ & $\mathrm{C} 2$ & $\mathrm{C} 3$ & D1 & CK & Unit \\
\hline & Benzo [a] pyrene & 0.2 & 0 & 0 & 0 & 0 & 0 & 0 & 0 & 0 & 0.1 & 0 & 0 & $\mathrm{mg} / \mathrm{kg}$ \\
\hline & Benzo [b] fluoranthene & 0.3 & 0 & 0 & 0 & 0 & 0 & 0 & 0 & 0 & 0.3 & 0 & 0 & $\mathrm{mg} / \mathrm{kg}$ \\
\hline & Benzo [K] fluoranthene & 0.1 & 0 & 0 & 0 & 0 & 0 & 0 & 0 & 0 & 0 & 0 & 0 & $\mathrm{mg} / \mathrm{kg}$ \\
\hline & Chrysene & 0.2 & 0 & 0 & 0 & 0 & 0 & 0 & 0 & 0 & 0.2 & 0 & 0 & $\mathrm{mg} / \mathrm{kg}$ \\
\hline & Dibenzo $[\mathrm{A}, \mathrm{H}]$ anthracene & 0 & 0 & 0 & 0 & 0 & 0 & 0 & 0 & 0 & 0 & 0 & 0 & $\mathrm{mg} / \mathrm{kg}$ \\
\hline & $\begin{array}{c}\text { Indene and }[1,2,3-\mathrm{CD}] \\
\text { pyrene }\end{array}$ & 0.1 & 0 & 0 & 0 & 0 & 0 & 0 & 0 & 0 & 0 & 0 & 0 & $\mathrm{mg} / \mathrm{kg}$ \\
\hline & Naphthalene & 0.17 & 0 & 0 & 0 & 0 & 0 & 0 & 0 & 0 & 0 & 0 & 0 & $\mathrm{mg} / \mathrm{kg}$ \\
\hline $\begin{array}{l}\text { Petroleum } \\
\text { hydrocarbons }\end{array}$ & $\begin{array}{l}\text { Petroleum hydrocarbon } \\
\text { (C10-C40) }\end{array}$ & 69 & 63 & 114 & 69 & 63 & 86 & 40 & 75 & 78 & 167 & 591 & 75 & $\mathrm{mg} / \mathrm{kg}$ \\
\hline
\end{tabular}

\subsection{Investigation based Conclusion}

The project survey for the former industrial land use, are now in the planning for residential land, the first phase of soil pollution condition investigation on present situation and the history surrounding the plot and plot the analysis of the possible pollution sources, preliminary judgment survey plot possible sources of pollution in the project mainly for auto repair shop in plots and temporary parking lot may cause pollution such as waste oil, Characteristic pollution factor is petroleum hydrocarbon.

In the second stage of soil pollution survey, preliminary sampling and analysis were conducted, and samples were collected, tested and analyzed. In this plot, 12 soil survey sites were set up, and 45 testing items were $\mathrm{pH}$, petroleum hydrocarbon and basic items. According to the laboratory test results, the concentration of heavy metals and volatile and semi-volatile pollutants in the soil of the site did not exceed the screening value standard of the first class land of the Soil Pollution Risk Control Standard for Construction Land in Soil Environmental Quality (GB36600-2018).

\subsection{Follow-up Recommendations}

At present, soil sample sampling and investigation of this plot have been completed, and the concentration of heavy metals and volatile and semi-volatile pollutants in the soil does not exceed the screening value standard of the first category of Soil Pollution Risk Control Standard for Construction Land in Soil Environmental Quality (GB36600-2018). In order to improve the soil pollution investigation of this plot, the groundwater and surface water of this plot should be sampled and tested.

\section{Acknowledgments}

This paper is supported by the following funds: National Key Research and Development Project (NO. 2019YFC1803501).

\section{References}

[1] Huang Qunhui. Industrial Development and Industrialization in China during 40 Years of Reform and opening up[J]. China Industrial Economics, 2018(09): 5-23.

[2] Shenghong $\mathrm{Xu}$, Guanguo Cheng, Jingqi Liu, Na Zhang. Analysis of land type change in old industrial relocation area based on GIS[J]. Environmental Protection of Xinjiang, 2021, 43(02): 43-50.

[3] Huang Wanbin, Yan Chunhua, Zhang Xiaonan, Qiu Guoyu. Effects of urbanization on groundwater volume, water quality and hydrothermal change and its
countermeasures[J]. Advances in Earth Science, 2020, 35(05): 497-512.

[4] GB36600-2018, Soil Pollution Risk Control Standard for Construction Land in Soil Environmental Quality[S]. 